\title{
THE BURDEN ON THE ACCOUNTANTS CAUSED BY THE COVID-19 PANDEMIC
}

\author{
Janka Dimitrova1, Olivera Gjorgieva-Trajkovska², Eftimija
} Dimitrova $^{3}$

UDC 657-057]:616.98:578.834\}-036.21(497.7)

657-057]:616.98:578.834\}-036.21(497.11)

657-057]:616.98:578.834\}-036.21(497.4)

657-057]:616.98:578.834\}-036.21(497.5)

1 "Goce Delcev" University - Faculty of Economics - Stip, Republic of North Macedonia, janka.dimitrova@ugd.edu.mk

2 "Goce Delcev" University - Faculty of Economics - Stip, Republic of North Macedonia, olivera.trajkovska@ugd.edu.mk

33niversity of London - London, United Kingdom, eftimijadimitrova@yahoo.com Abstract

The Covid-19 Pandemic imposed many changes and challenges in the daily lives of the citizens and the functioning of the business sector. For more effective protection, precautionary measures were adopted and restrictions on the movement of citizens were introduced. Vulnerable categories of employees (chronically ill, pregnant women, mothers with small children, ....) were advised not to go to work. A number of businesses have disrupted the production process both to prevent the spread of the pandemic and due to canceled orders from the customers. Many workers lost their jobs. Administrative workers perform their duties from home. Many companies (depending on the industry) have also adapted and are working from home.

In order to alleviate this situation, six packages of financial support measures were adopted, which were intended for the business sector and the citizens, in order to provide basic conditions for normal functioning and living. The financial support for the business sector was conditioned by the fulfillment of certain criteria (income, number of employees, ....) and a request had to be submitted within the set deadlines which were too short. For submitting the requests for the financial support, for the interest-free loans, for the deferred payment of liabilities, as well as for all liabilities arising from the Covid-19 pandemic (monitoring the movement of income, the number of employees, the amount of salaries paid, warnings about unpaid debts, administrative deductions from salary, ...) accountants were obliged. Despite all the risks posed by the pandemic, accountants had to work because they were the logistical support to the business sector and responsible for the accuracy of the information presented in the financial statements and tax returns.

Accountants are an extremely important link between the business sector and the state. They are responsible for calculating all taxes and contributions that fill the budget and on their shoulders have implemented all measures (financial support, deferred payment of interest, interest-free loans, ....) intended to alleviate the situation caused by the Covid-19 pandemic in the economy. Therefore, the purpose of this paper is to conduct research to identify the problems encountered during the operation under Covid 19. The research will 
be conducted by means of a questionnaire submitted to the accounting firms registered in the register of the Institute of Accountants and Certified Accountants. According to the answers to the questionnaire, we will give suggestions for overcoming the problems and improving the situation

\section{Keywords: Covid-19 pandemic, anti-crisis measures, accountants, financial support Introduction}

Accounting is a discipline that deals with the recording, classification, interpretation and communication of financial information. Accounting is the collection and processing of data based on accounting documents, preparation and maintenance of trade / business books and compilation of annual accounts and / or financial reports in accordance with law. (1) Practitioners are called accountants, who are responsible for the truthfulness and the accuracy of the information presented in the financial statements. This means that they are the last filter before the information on the financial condition and success from internally available to become publicly available. This responsibility for accountants in practice, applies to those who are employed in medium and large entities, where there is a large number of employees in the administration and established segregation of duties. Small and micro entities usually for all administrative matters conclude an outsourcing service agreement with the Accounting Company, where the certified accountant employed in the Accounting Company, in addition to keeping an accounting records, performs a number of other activities in the field of finance (payment of liabilities and collection of receivables, calculation and payment of salaries, ....), law (preparation of legal acts, decisions, ...), registration and deregistration of employees in the Employment Agency, submission of sick leave in the Health Insurance Fund and many other things.

The Covid-19 pandemic has imposed a number of challenges and adjustments that we were not aware of before that would become commonplace. Each company reorganized in its own way and organized its business process, all in order to minimize the consequences of the pandemic and keep it alive. The legislature and the executive government in all countries (each according to the conditions and possibilities) prescribed measures to mitigate the consequences caused by the Covid-19 pandemic. In the Republic of North Macedonia were adopted 6 packages of measures, with which the state tried to alleviate the difficult financial situation of the most affected sectors. (2)

The accountants were the ones who carried the burden of implementing all 6 packages of measures on their shoulders, because numerous calculations and analyzes had to be made to determine who meets the criteria for submitting a request for financial support, to monitor the fulfillment of the criteria after receiving the financial support and finally to submit a request for turning the financial support into a grant. In fact, they were also exposed to the possibility / danger of being infected with the coronavirus.

For the additional burden that the accountants faced during the operation in conditions of Covid19 , how they implemented the measures for financial support and the problems they faced, we conducted a research through a questionnaire which contained 20 questions. The questionnaire was submitted to the accounting firms registered in the register of the Institute of Accountants and Chartered Accountants (ISOS). The questionnaire was distributed through the Google Forms application, which based on the answers to the questions, automatically created the graphs. 
The questionnaire was answered by 291 accountants, so we believe that the answers are relevant to ascertain the situation and make suggestions for overcoming the problems faced by accountants to improve the situation.

\section{Research results}

In this section, the research questions, the answers as well as commentary will be given.

1. Were the financial support measures adopted in a timely manner?

$90 \%$ of accountants think that the measures were delayed, and only $10 \%$ think that the measures were adopted on time. The Covid-19 pandemic caused numerous health and business problems for both individuals and legal entities, which required financial support that the state implemented through 6 packages of measures conditioned by meeting the criteria for which accountants had to make a calculation that meets the requirements for application.

2. Did the frequent change of criteria and unclear criteria for granting financial support lead to problems in the application? 


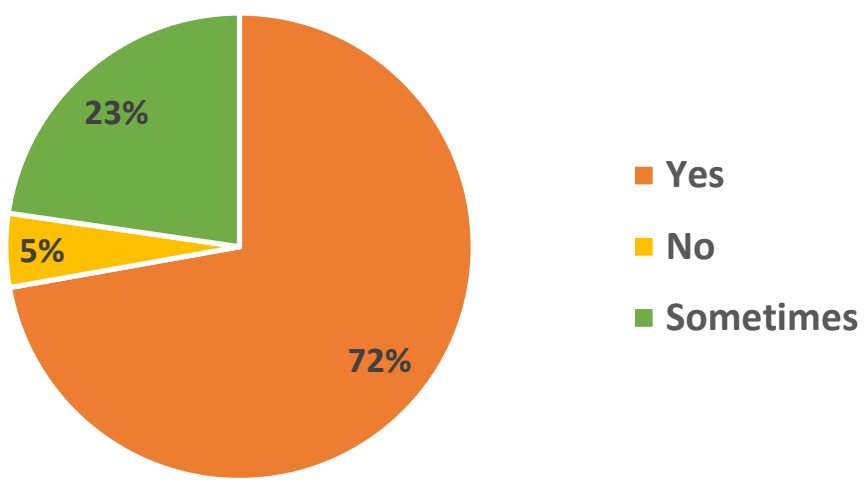

Initially, the criteria for financial support measures changed several times. The application deadlines were short considering that these were additional obligations (besides the regular ones) for the accountants. As many as $72 \%$ of accountants think that the unclear criteria and the frequent change of criteria created problems for them when preparing applications for financial support.

3. Do you think that the comparison periods that were the benchmark for determining the criteria for financial support were appropriate?

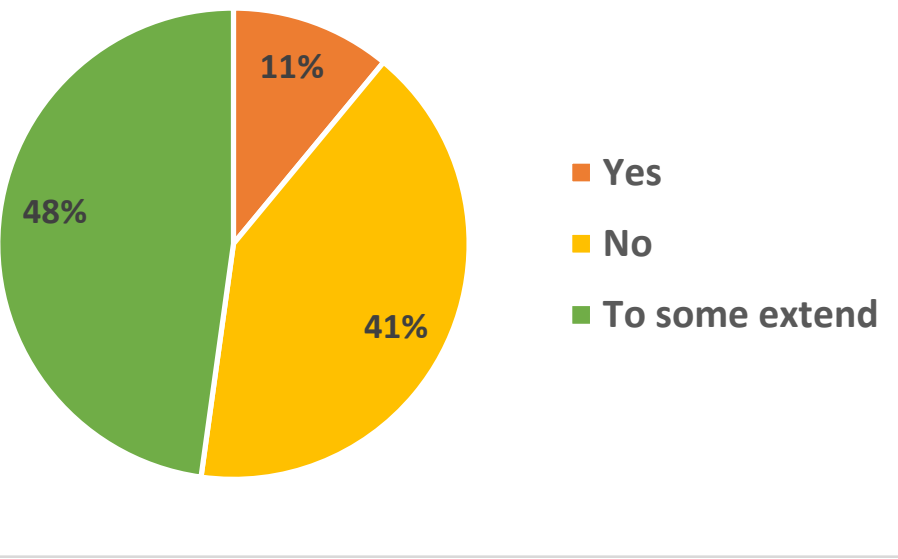

Accountants think that the comparison periods that were the benchmark for determining the criteria of financial support were not the most appropriate. The set criteria imposed an additional obligation on the entities that are quarterly taxpayers or not VAT payers at all, due to the need to determine the income from previous periods on a monthly basis.

4. According to which criteria should the financial support be granted? 


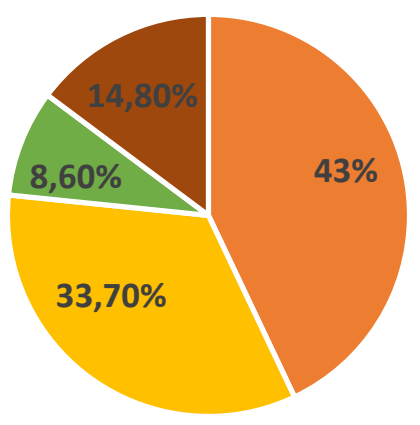

- Income from regular activities in the current month in relation to the income from regular activities from the same month in $\mathbf{2 0 1 9}$

- Income from regular activities in the current month in relation to the average income from regular activities from 2019

- Income from regular activities per employee in the current month in relation to the income from regular activities per employee from the same month in 2019

- Income from regular activities per employee in the current month in relation to the average income from regular activities per employee from 2019

The opinion of the accountants is that the best criterion for granting financial support would be the income from regular activities in the current month of 2020 compared to the same month of 2019.

5. Were the deadlines for submitting applications for financial support sufficient?

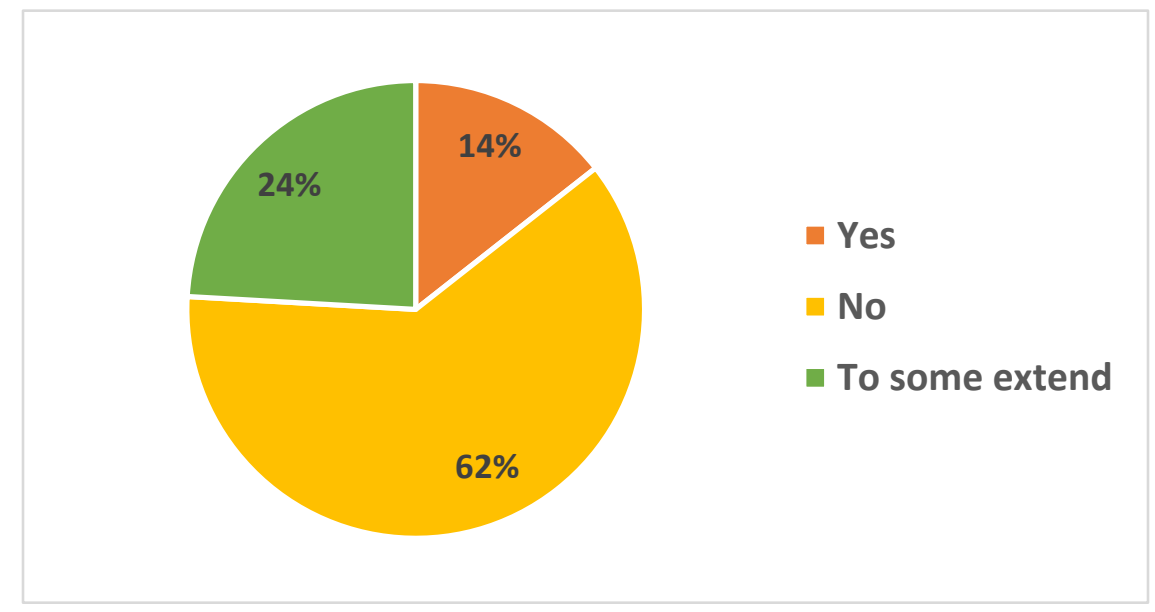

$62 \%$ of accountants think that the deadlines for submitting applications for financial support wre short.

6. Do you think that the financial support should have been unconditional (without obligation to return it or invest)? 


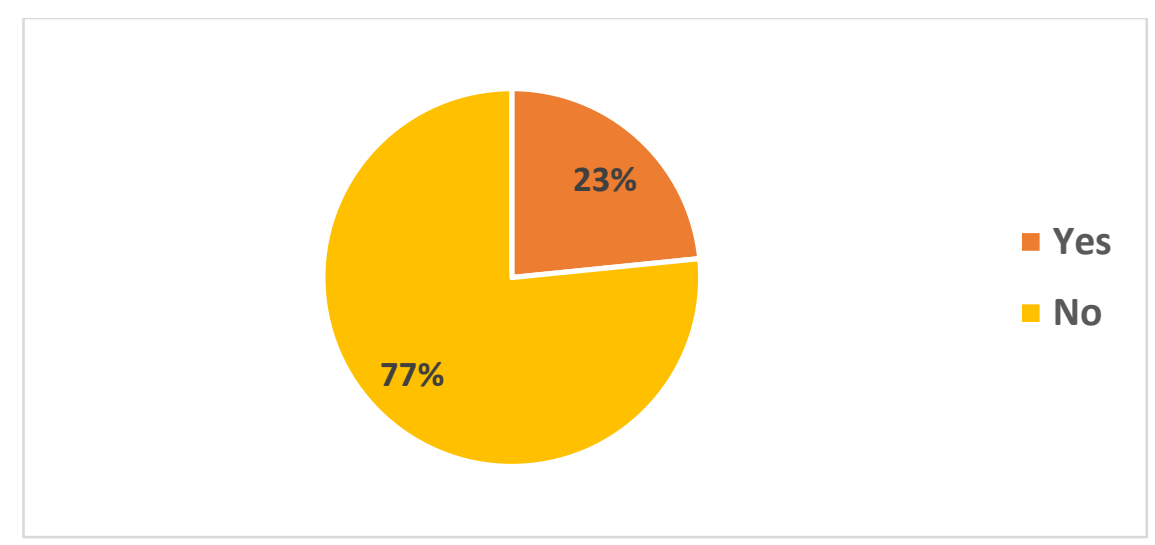

Financial support was not unconditional. Additionally, a request was submitted for conversion of the support into a grant or refund. $77 \%$ of accountants think that financial support should have been unconditional.

7. Have you had a case of sick accountants / certified accountants from covid-19 in your accounting company?

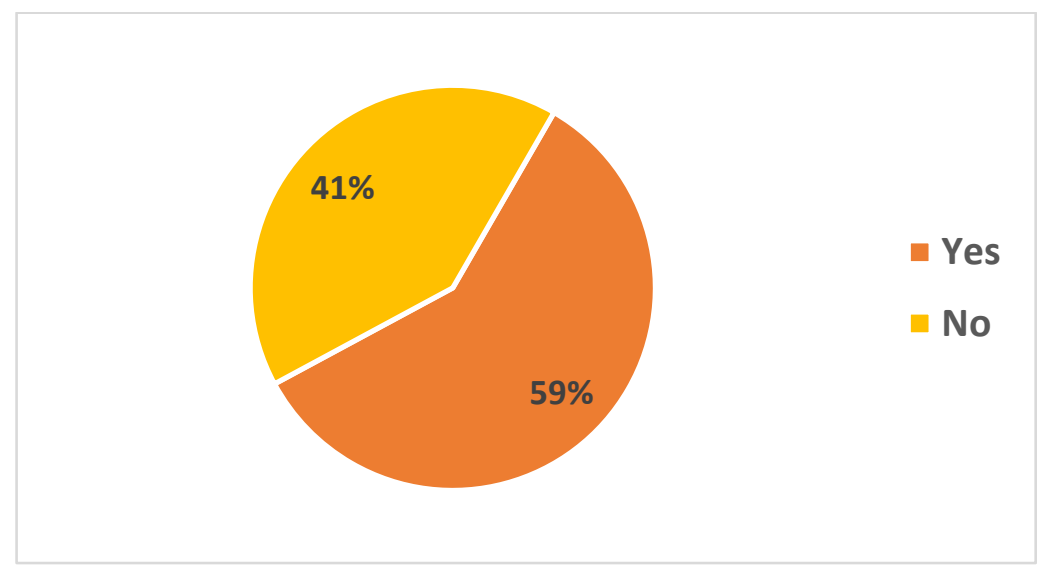

Of concern is the fact that as many as $59 \%$ of accountants were infected with covid- 19 . 
8. If the answer to the previous question is yes, how did you perform the work responsibilities (you can choose multiple answers).

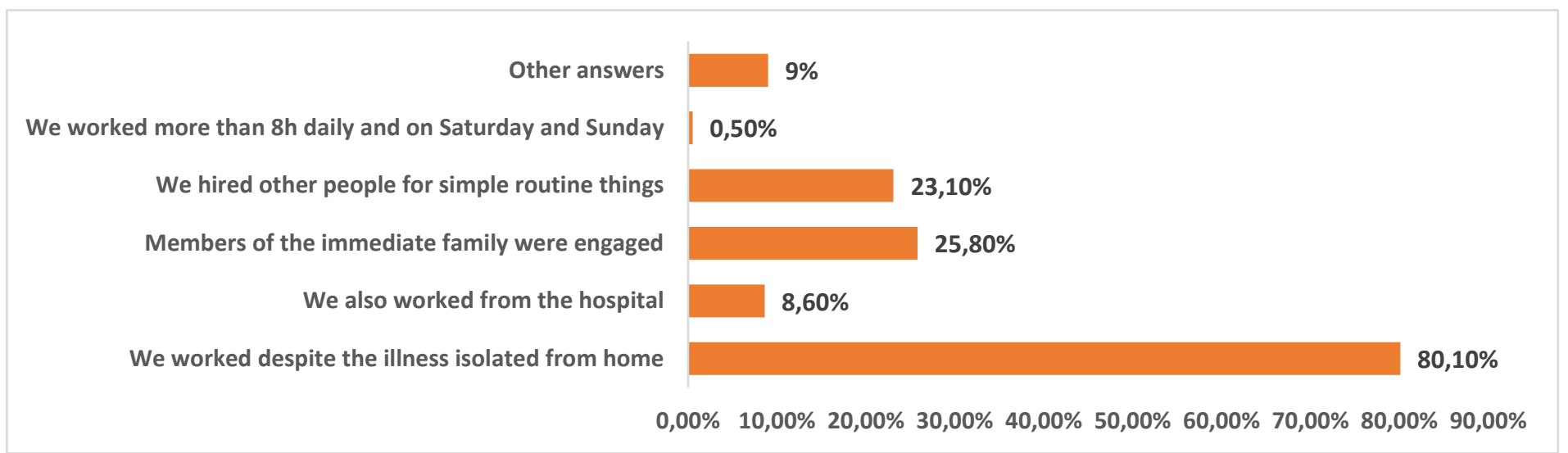

Accountants' answers speak to their responsibility to work and their loyalty towards customers. Despite the health problems caused by Covid-19, they still performed their duties. For the business sector to function, accountants even in a pandemic, had to provide consulting support on a daily basis, facing the risk of being infected with the virus. Almost $8,6 \%$ of accountants worked even though they were hospitalized.

9. In conditions of pandemic, with impaired health and under pressure of deadlines for submitting applications / requests (Requests for financial support, tax returns, annual account and financial statements, salary calculations, registration of the real owner, ...), is it possible for errors to occur in the submitted documents?

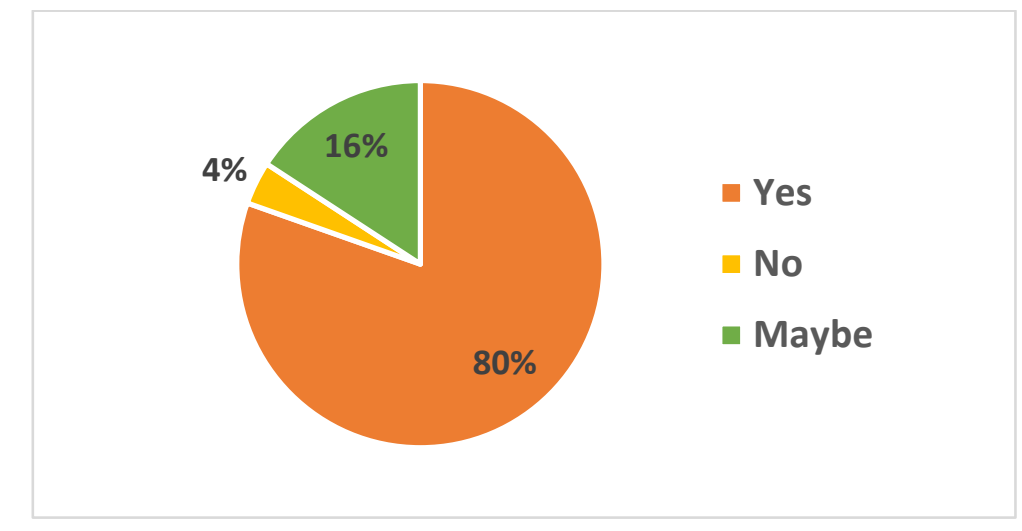

Many accountants were infected and sick, but still had to work to meet deadlines. Due to this situation (due to illness and under pressure from deadlines) often omissions and errors that need to be corrected occurred and faced with control by the Public Revenue Office (PRO). In conditions of pandemic and under the pressure of short deadlines, as many as $80 \%$ of accountants think that it is possible that errors in operations have occurred.

10. Did you have a case when submitting reports to the Public Revenue Office that the Etax system did not work? 


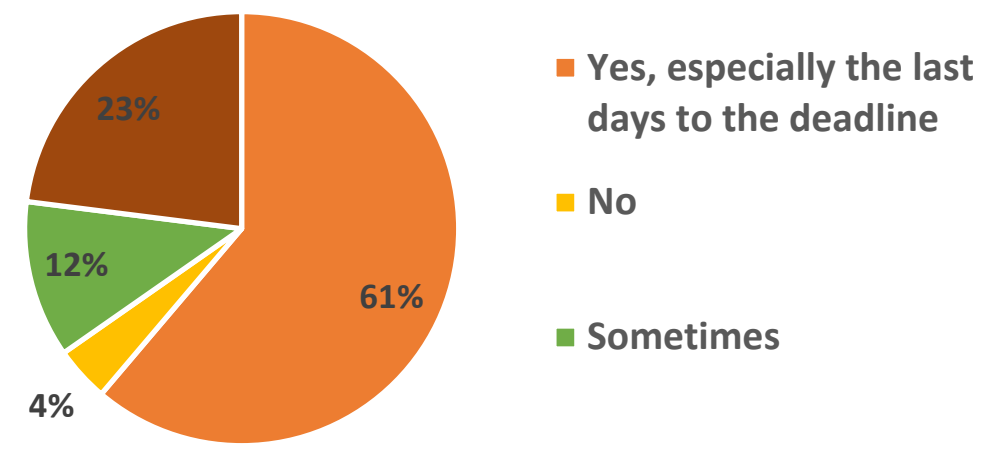

An additional burden for accountants is the non-functioning of the e-tax system on the Public Revenue Office platform. This problem is from the very introduction of the system in operation. $61 \%$ of accountants face the problem of non-functioning of the electronic tax record system.

11. Were you forced to submit the applications after the regular working hours due to the non-functioning of the electronic system of the Public Revenue Office?

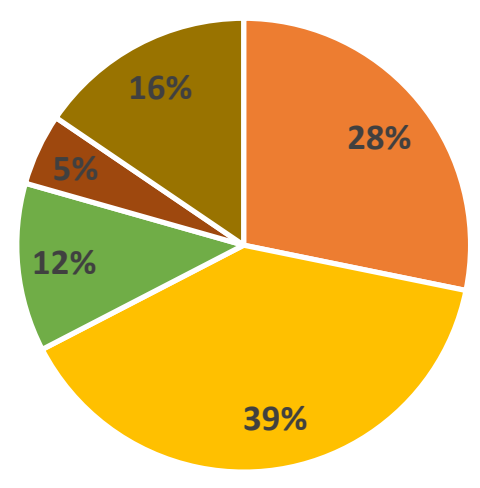

- Yes, usually from 16-20 o'clock

Yes, usually from $\mathbf{2 0 - 2 4}$ o'clock

- Yes, usually from 00-04 o'clock

- Yes, usually from 04-08 o'clock

- No, we were submitting them during regular working hours

The filing of electronic documents on the e-tax system, is usually done by the accountants outside of the regular working hours, in the late hours of the night. Only $16 \%$ of the accountants submitted their tax returns in regular working hours, which means that it is inevitable to upgrade the e-tax system for timely submission of the prescribed forms. 
12. Why do you submit the prescribed forms in the last days before the submission deadline (you can choose more answers)?

Due to additional requirements / obligations (which are not accounting matters) by the business sector

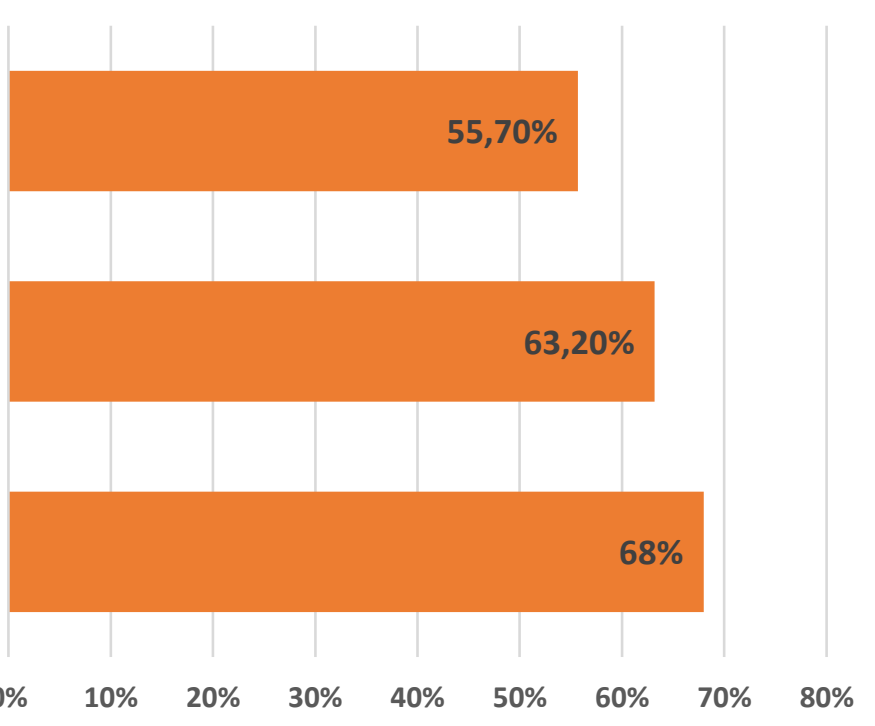

One of the biggest reasons for submitting tax returns in the last days of the prescribed deadlines is due to untimely submission of documents by the management of the companies and due to additional obligations imposed on accountants, which are not accounting matters.

13. When submitting the annual accounts, financial statements, registration of the real owner, etc., on the Central Registry platform, did you have a case when it did not work?

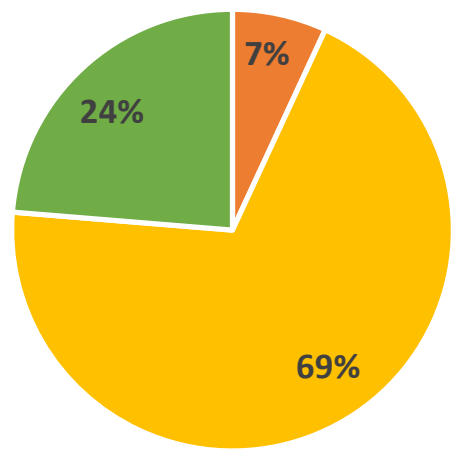

- Yes

No

- Sometimes

Unlike the non-functional system of the Public Revenue Office, the system for electronic submission of annual accounts to the Central Registry works quite well, i.e. only $7 \%$ of accountants faced problems in submitting annual accounts and other submissions to the Central Registry. 
14. Did you charged increased compensation for the additional obligations for calculating and submitting financial support applications or did you receive a salary increase from your clients / employers?

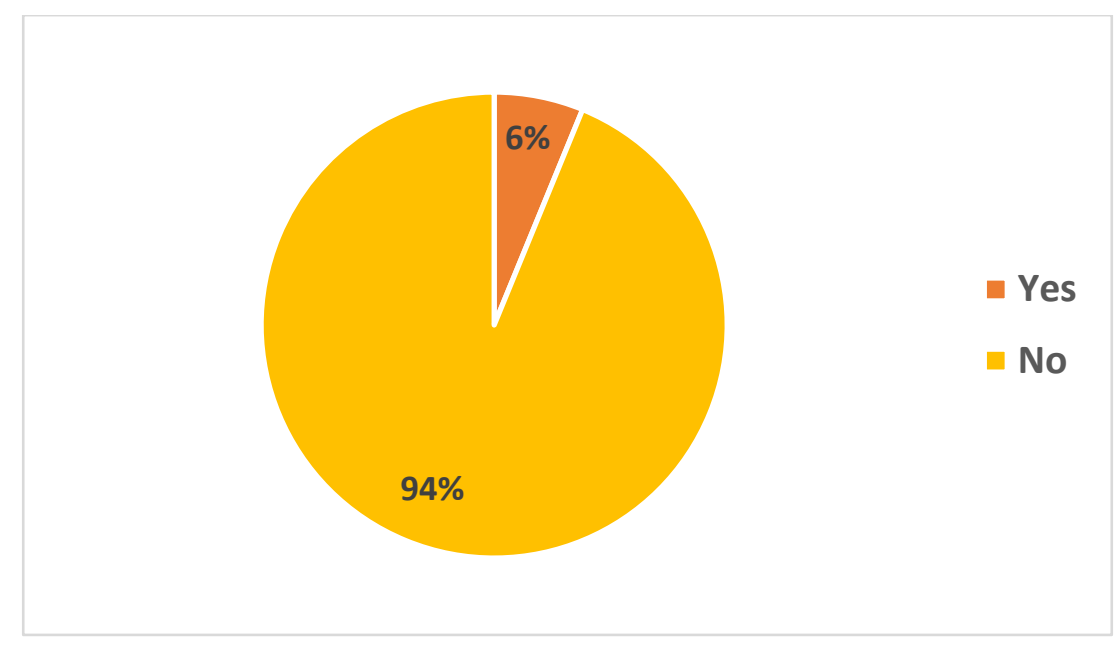

Despite increased obligations, increased risk of infection, work and when they are ill, accountants have not received a salary increase / fee for the accounting services. For the additional obligations, $94 \%$ of accountants did not receive additional compensation for the services rendered due to the Covid-19 pandemic.

15. If you answered yes to the previous question, is the compensation / salary increase charged appropriate?

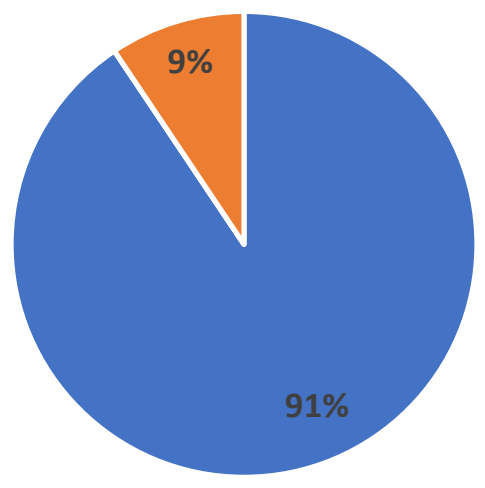

- We had a slight increase in the fee / salary in relation to the increased obligations

- We had a corresponding increase in the fee / salary in relation to the increased obligations

Those accountants who received additional compensation for only $9 \%$, the fee increase was at an appropriate level. 
16. The total income of the accounting firms in 2020 compared to 2019 is

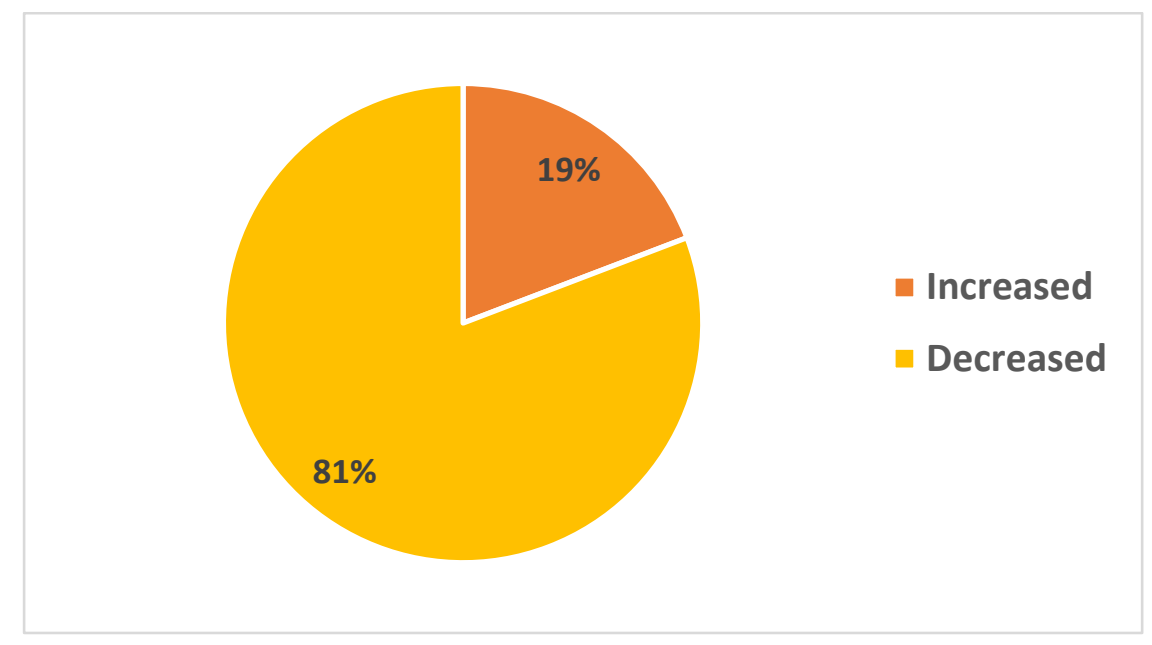

17. Do you have problems collecting receivables from your customers?

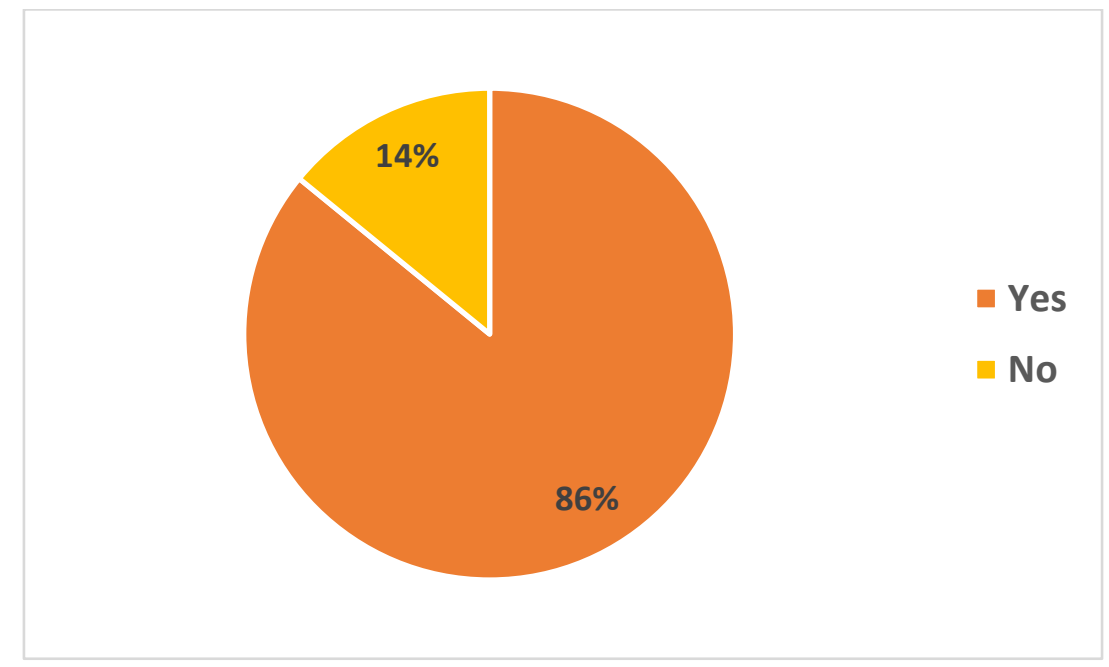

The Covid-19 pandemic has caused decreased income from accounting services and collection problems. In $81 \%$ of the accounting companies the income in 2020 has decreased and in $86 \%$ there were problems in the collection of the fee for the performed accounting service.

18. Do you think that accounting firms should be given financial support? 


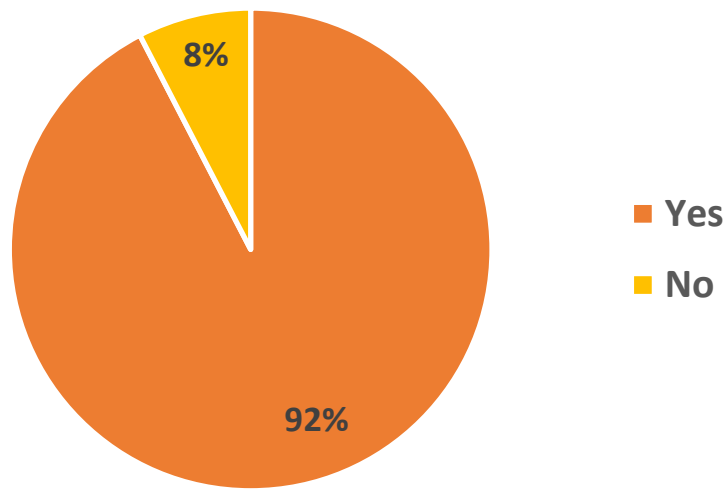

19. If the answer to the previous question is yes, according to which criteria should the amount of financial support be determined?

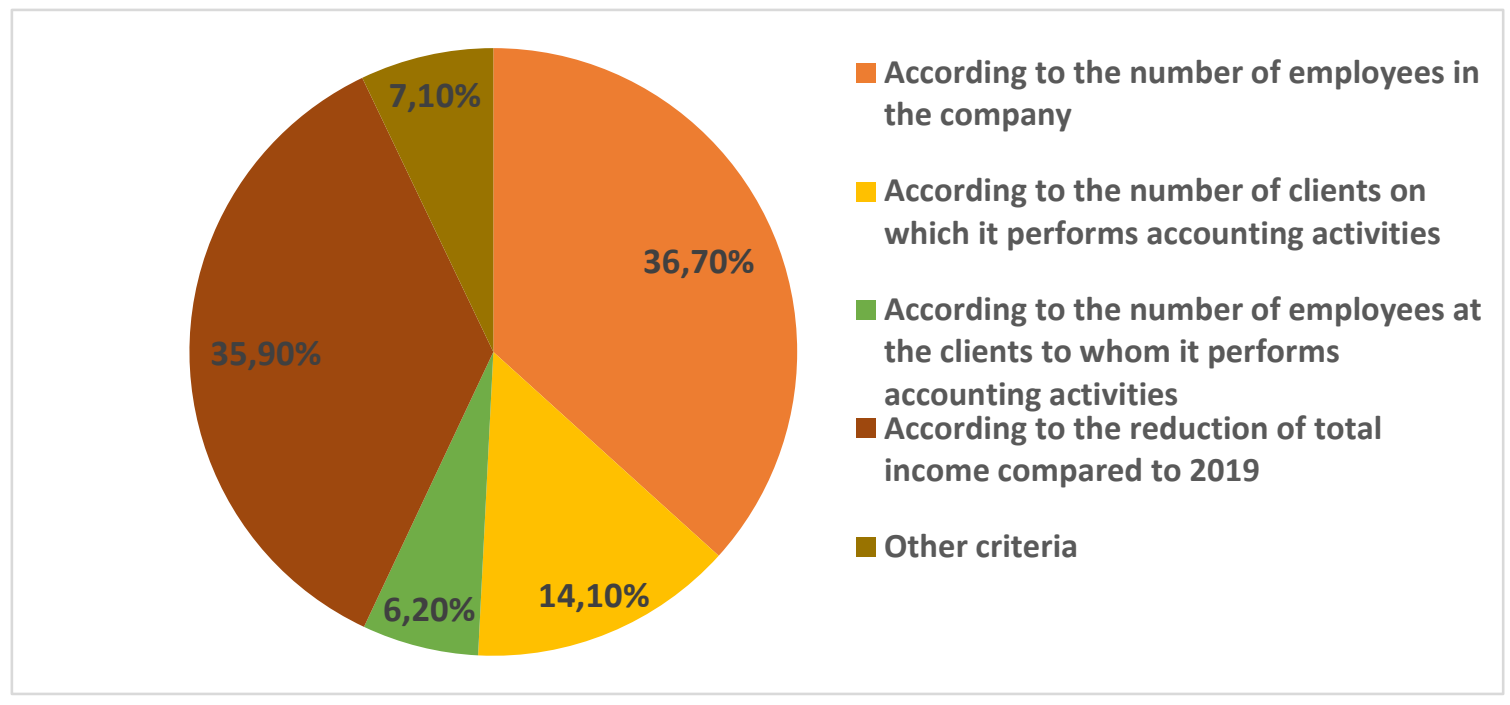

20. Should the financial support of accounting firms be unconditional (without the obligation to return it or to invest)? 


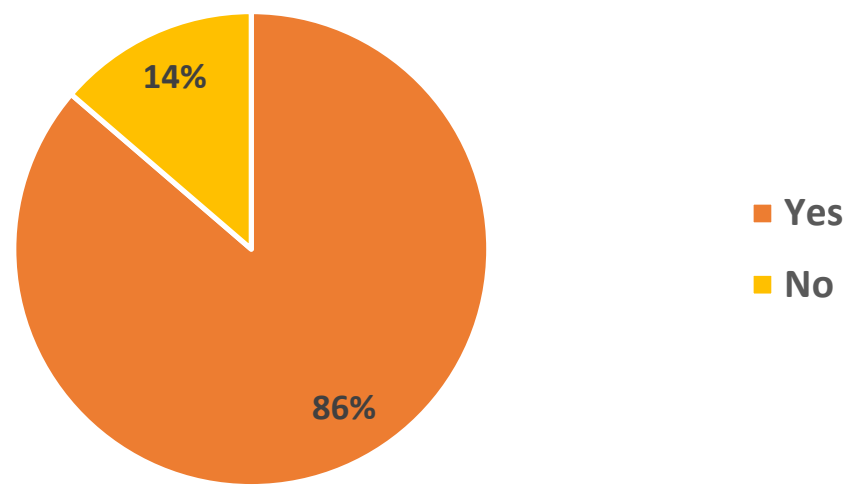

The accountants did not receive any financial support from the state, despite their contribution to the calculation of taxes and other public duties that fill the state budget. The accountants through the Chamber of Accountants of Macedonia only requested time, ie extension of the deadlines for submission of the calculations, but they did not get an understanding for that either. (3)

\section{Financial support for mitigation of the consequences of COVID-19, in Macedonia, Serbia, Croatia and Slovenia}

In Macedonia, the financial support was in several forms, i.e. interest-free loans, funds to encourage investment, salary for employees of entities that had reduced revenues by more than $30 \%$ compared to the previous year, support for citizens with tourist vouchers, etc.

In the Republic of Serbia, a program was also adopted for financial support of business entities for liquidity maintenance and working capital due to the difficult economic conditions caused by the COVID-19 pandemic. The financial support was conditioned by fulfilling the conditions for acquiring the right to use it. (4)

Financial support was also granted to the citizens of the Republic of Serbia for mitigation of the consequences of COVID-19. (5) Financial support was granted to the citizens and the unemployed in Kosovo and Metohija. (6)

In the Republic of Croatia, financial support was provided for job preservation, Covid loans for micro, small and medium enterprises with an interest rate of $0.25 \%$, support for working capital, etc. (7)

Numerous financial support measures were adopted in the Republic of Slovenia for both citizens and the self-employed, farmers and micro, small and medium enterprises to mitigate the consequences of the COVID-19 crisis. (8)

\section{Conclusion}


The COVID-19 pandemics caused numerous problems from a health and business aspect to both individuals and legal entities, which required financial support that the state implemented through 6 packages of measures conditioned by meeting the criteria for which accountants had to make a calculation whether the legal entities meet the criteria for application. In the beginning, the criteria envisaged by the measures were changed several times. The application deadlines were short considering that these were additional obligations (besides the regular ones) for the accountants. Comparative calculation periods for meeting the criteria for financial support were in different tax periods which caused additional problems in the calculation. Financial support was not unconditional. Additionally, a request was submitted for conversion of the support into a grant or refund.

For the business sector to function, accountants even in a pandemic, had to provide consulting support on a daily basis, facing the risk of being infected with the virus. Many accountants were infected and sick, but still had to work to meet the deadlines. In this situation (due to impaired health and under the pressure of deadlines) often occurs omissions and errors that need to be corrected and faced with control by the Public Revenue Office.

An additional burden for accountants is the non-functioning of the e-tax system on the Public Revenue Office platform. This problem is from the very introduction of the system in operation. The filing of electronic documents on the e-tax platform, accountants usually do outside of regular working hours, in the late hours of the night. An upgrade of the e-tax system for timely submission of the prescribed forms is inevitable. The documents are submitted in the last days of the prescribed deadlines due to untimely submission of documents and additional obligations that are imposed on accountants, and are not accounting matters. In order to overcome this situation, greater diligence on the part of the management for timely completion of the documentation that the accountants need to process and record is inevitable.

Despite the increased obligations, increased risk of infection, work and when they are ill, accountants have not received a salary increase / fee for accounting services. The pandemic caused a decrease in the revenues from accounting services and problems in their collection. The accountants did not receive any financial support from the state, despite their contribution to the calculation of taxes and other public duties that fill the state budget. The accountants only asked for time, i.e., extension of the deadlines for submission of the calculations, but they did not get an understanding for that either. This points to the fact that greater understanding and respect is needed for accountants from state bodies and institutions for the problems they face.

In all analyzed countries, the financial support for legal entities is not unconditional, ie it should have been returned depending on the award criteria. Also, the burden of submitting applications for financial support was borne by accountants.

\section{Bibliography}

1. Law on Accountants and Certified Accountants https://isos.com.mk/index.php/zakon-za-smetkovoditeli-2

2. https://vlada.mk/ekonomski-merki-covid19

3. https://chamber.mk/tag/komora-na-smetkovoditeli/

4. https://fondzarazvoj.gov.rs/cir/proizvodi/likvidnost-covid19 
5. http://www.pravno-informacionisistem.rs/SIGlasnikPortal/eli/rep/sgrs/skupstina/zakon/2021/40/6/reg

6. https://www.rts.rs/page/stories/ci/story/5/ekonomija/4383502/ana-brnabic-isplatapomoci-kim-pocetak.html

7. https://www.koronavirus.hr/vladine-mjere/101

8. https://www.gov.si/teme/koronavirus-sars-cov-2/odpravljanje-posledic-epidemije/petipaket-ukrepov-za-omilitev-posledic-epidemije-pkp5/ 